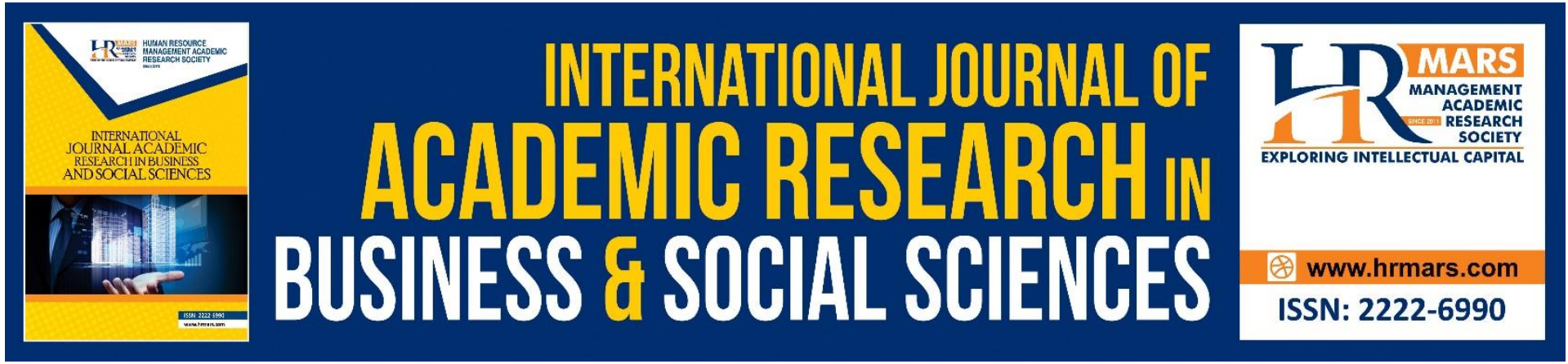

\title{
Employee Empowerment, Knowledge Management and Decision-making Agility; Mediating Role of Extra-role Performance
}

\author{
Mahmoud Ali Salahat
}

To Link this Article: http://dx.doi.org/10.6007/IJARBSS/v11-i7/10327

DOI:10.6007/IJARBSS/v11-i7/10327

Received: 12 May 2021, Revised: 19 June 2021, Accepted: 14 July 2021

Published Online: 27 July 2021

In-Text Citation: (Salahat, 2021)

To Cite this Article: Salahat, M. A. (2021). Employee Empowerment, Knowledge Management and Decisionmaking Agility; Mediating Role of Extra-role Performance. International Journal of Academic Research in Business and Social Sciences, 11(7), 960-977.

Copyright: (c) 2021 The Author(s)

Published by Human Resource Management Academic Research Society (www.hrmars.com)

This article is published under the Creative Commons Attribution (CC BY 4.0) license. Anyone may reproduce, distribute, translate and create derivative works of this article (for both commercial and non-commercial purposes), subject to full attribution to the original publication and authors. The full terms of this license may be seen

at: http://creativecommons.org/licences/by/4.0/legalcode

Vol. 11, No. 7, 2021, Pg. 960 - 977

http://hrmars.com/index.php/pages/detail/IJARBSS

JOURNAL HOMEPAGE

Full Terms \& Conditions of access and use can be found at http://hrmars.com/index.php/pages/detail/publication-ethics 


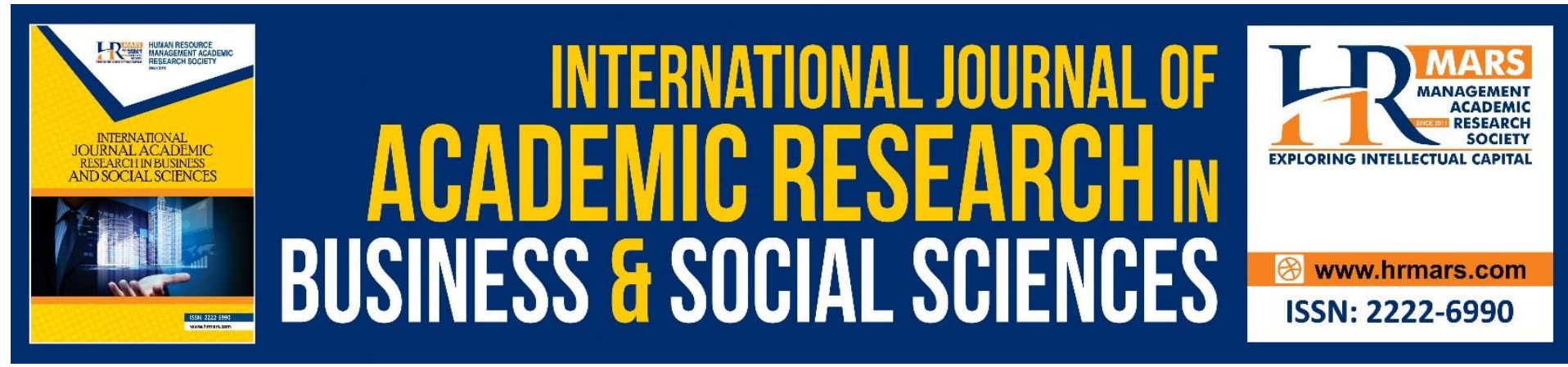

\title{
Employee Empowerment, Knowledge Management and Decision-making Agility; Mediating Role of Extra-role Performance
}

\author{
Mahmoud Ali Salahat \\ Asst. Prof. College of Administrative and Financial Sciences, Palestine Ahliya University \\ (PAU) \\ Email: Mahmoud@paluniv.edu.ps
}

\begin{abstract}
Universities in Palestine are facing many problems in terms of organizational performance and its ability to agile (1) financing problems and fund raising (2) scientific research challenges (3) managerial practices challenges (4) the level employees' efficiency. Besides, studies on resources and capabilities that enable organization to be agile is still nascent. This study aims to examine effect of employee empowerment and knowledge management on decisionmaking agility. Moreover, It examines the mediating role of extra-role performance between employee empowerment and knowledge management on one hand and decision-making agility on the other hand in the Palestinian context. Using data from a survey of 289 employees of Palestinian universities, this study tests a structural equation model that relates to employee empowerment, knowledge management, extra-role performance and decisionmaking agility. The results of the study revealed that employee empowerment and knowledge management impact decision-making agility indirectly. On the other hand, the relationship between employee empowerment and knowledge management and decision-making agility is mediated by extra-role performance. And this is the main contribution of the present study since extra-role performance has not been deployed in this place according to literature review.
\end{abstract}

Keywords: Employee Empowerment, Knowledge Management, Extra-Role Performance, And Decision-Making Agility.

\section{Introduction}

It is obvious stated that today's organizations need to adjust and act swiftly in current highly dynamic business environment (Yousif \& Pessi, 2016). They must observe indications and signals from their internal and external environments, and also respond adequately and quickly (Ravichandran, 2018). In other words, they must become agile (Rulinawaty \& Samboteng, 2020). Empirical studies revealed that organization capable of responding quickly and with innovative actions to changes in its business environment have been able to reinforce its performance (Ferrier \& Lyon, 2004). Furthermore, Organizational agility helps organizations to deal with the changes efficiently and quickly (Sukati et al., 2012; Winby \& Worley, 2014), improving quality (Sohrabi et al., 2014), using advanced technology effectively, 
achieving excellence in labor market (Hosein \& Yousefi, 2012), cutting costs, optimal using of organizational resources, increasing productivity, providing a variety services (Al-Romeedy, 2019), and taking advantage of market opportunities (Ashori et al., 2015)

Unfortunately, Palestinian educational sector have many problems in terms of organizational performance and its ability to agile. According to the Palestinian information center, Palestinian educational sector faces the following challenges (1) financing problems and fund raising (2) scientific research challenges (3) managerial practices challenges (4) the level employees' efficiency (Center, 2018). Moreover, other study revealed that Palestinian academicians are suffering from lack of using e-learning during COVID-19 Pandemic, and Palestinian universities need to reinforce its strategic and contingency plans (Rashwan, 2020). Traditionally, many researches have examined many organizational variables and their effects on the performance of organization (Tallon \& Pinsonneault, 2011), studies on resources and capabilities that enable organization to be agile is still nascent (Ravichandran, 2018). And this is the motivation to conduct this study. Hence, this study aims at investigate the relationship between internal organizational functioning and organizational agility. More specifically, this study focuses on the effect of employee empowerment and knowledge management on decision-making agility through their impact on extra-role performance. And the main contribution of this study is embodied in using extra-role performance as a mediator among the above mentioned variables since it has not been used earlier in this place according to literature review.

\section{Literature Review and Hypotheses Development Employee's Empowerment}

Employee empowerment is defined as the authority placed in employee's hands, specifically the control over the organizational resources usage and responsibilities in order to achieve the organizational objectives (Emam et al., 2019). It refers to significant employment of employees, their feelings of competence, contributions and autonomy decision-making or application of leadership (Erdavit et al., 2019). Traditionally, authority had been defined as a managerial prerogative. Along the same line, the philosophy of employee empowerment represents the new domains of decision making process and clarified how it can enhance the organizational performance since leaders and employees are both engaged in decision making process (Purnomo et al., 2020).

Empowerment enables employees to feel that they are essential part of organizational success. it builds high commitment among employees and develops a sense of high loyalty to the organization. (Ihuoma et al., 2019). Empowerment leads to greater use of the knowledge, abilities and skills of the human pool, It enhances team working and if there is meaningful participation, it can lead to the successful implementation of change programs (Mohapatra \& Sundaray, 2018). The benefits of employee empowerment can be achieved when employees have the needed incentives to carry out their responsibilities and duties and make decisions without referring to higher managerial levels (Alromaihi et al., 2017). More importantly, employee empowerment becomes a worldwide well known practice since there is more than $70 \%$ of the organizations have implemented some empowerment initiatives for their human force globally (Hasan, 2020).

In a competitive environment Every employee in an organization has his or her role to play, in this way value is created and added to the customers (Nasiri et al., 2018). Furthermore, organizations must be leaner, faster and provide a better service quality, be more efficient, 
and more profitable, and these requirements made the role of empowered and proactive service worker is more essential (Alalie et al., 2019). An empowered employee can be one of the critical tools that an organizations have in their arsenals. Through employees empowerment, the organization gives the employee incentives and vision, herewith increasing motivation, productivity and performance. When employees feel empowered, they will often seek out new procedures and even products within an organization and encourage innovation (Murray \& Holmes, 2021).

Theoretically, employee empowerment and organizational agility can be linked through contingency theory (Rastegari et al., 2020; Read III, 2020; Segerman, 2020). This linkage takes its place because the rabid changings in business environment has a crucial impact on employment relationships during the last decades. Furthermore, the emerging relationship focuses on maximizing organizational flexibility and synchronously improving employee performance (Shukla et al., 2018). Actually, many organizations use employee empowerment as a retention strategy because it can create a desired environment, boost cooperative working relationships and help the employee themselves to reinforce their leadership skills and abilities (Jia et al., 2014). In fact, surviving ability of many organizations is threatened by incompatibility or inconsistency with environmental changes (Abtahi \& Abbasi, 2007). Huge environmental changes in today's business world requires organizational flexibility in order to ensure their survival, reinforcing empowerment and giving the needed freedom of action to employees is a critical methodology for developing performance and actualizing survival in today`s organizations (Asgarnezhad Nouri \& Mir Mousavi, 2020). Moreover, many studies used employee empowerment as a dimension of organizational learning (Akhtar \& Arif, 2011). Empirically, literature review revealed that few researchers examined the effect of the employee empowerment on organizational agility (Asgarnezhad Nouri \& Mir Mousavi, 2020; Elgamal, 2018; Horabadi Farahani \& Salimi, 2015), and concluded that, employee empowerment has a positively relationship with organizational agility. Based on that this study hypothesizes the following:

H1: There is a significant positive relationship between employee empowerment and decision-making agility.

\section{Knowledge Management}

Knowledge management is one of the most vital resources to all companies and it is the right way to build a successful and reliable team (Tooranloo \& Saghafi, 2018). Knowledge management is defined as a set of initiatives, activities and strategies used by organizations to create, store, apply and transfer the knowledge in order to develop the organizational performance (Govareshki et al., 2017). It refers to an organization's external and internal performance including, customer satisfaction, brand reputation, loyalty strategies, stakeholder policies, and employee engagement and retention (Demir et al., 2021). Also, it can be described as the process of identifying and leveraging collective knowledge to foster competitiveness, and to enhance the organizational ability of innovativeness and responsiveness to environmental changes (Santoro et al., 2018).

Knowledge management maximizes the exchange of information among stakeholders, promoting the generation of innovations and contributes critically in cooperation within the organization's departments (Singh \& El-Kassar, 2019). Furthermore, managing the flow of information in the organizations creates changes in knowledge management that is beneficial to organizations, in other words, knowledge management helps organizations to share information from economic sectors and different groups of employees and then achieve an 
important strategic gains (Nisar et al., 2019). In fact, large number of organizations (including public agencies, private companies and non-profit entities) have actualized the value of knowledge management as a critical tool for profitability, competitiveness and surviving (Omotayo, 2015). Along the same line knowledge management can be identified through two forms which are implicit and explicit. Implicit knowledge refers to intangible knowledge forms such as individual experience and points of views whereas explicit knowledge is defined as a bundle of codified knowledge in the form of documents, organizational manuals and database (Martins et al., 2019). Literature review revealed that knowledge management is considered as a strategic resource to support risk management abilities of the organizations and to improve organizational success (Manab \& Aziz, 2019). Some studies concluded that knowledge management provides solutions and highlight unknown risks in terms of environmental complexity (Martins et al., 2019).

Theoretically, this study considered knowledge management as one of its independent variable. According to literature review many scholars used knowledge management as a dimension of organizational learning (Hong, 1999; Pun \& Nathai-Balkissoon, 2011). Furthermore, many scholars have studied the organizational learning from the perspective of contingency theory (Alonso-Almeida et al., 2016; Jiang \& Li, 2008). Along the same line the relationship between knowledge management and organizational agility had been studied from the perspective of contingency theory (Khan \& Wisner, 2019; Pantouvakis \& Bouranta, 2017). Some prior studies examined the relationship between knowledge management and organizational agility and concluded that knowledge management has a positive relationship with organizational agility (Ashrafi et al., 2006; Liu et al., 2014; Mehdibeigi et al., 2016). Based on that this study hypothesizes the following:

H2: There is a significant positive relationship between knowledge management and decision-making agility.

As mentioned earlier employee empowerment and knowledge management have been treated as dimensions of organizational learning. Furthermore, According to literature review, the impact of the organizational learning on organizational agility has several contradictions. Some researchers concluded that there is a positive and significant relationship between organizational learning and organizational agility (Bahrami, Kiani, Fallahzadeh, et al., 2016; Bahrami, Kiani, Montazeralfaraj, et al., 2016). And others assured that organizational learning has not a positive and significant effect on organizational agility (Putri \& Mangundjaya, 2020). Based on the above debate about the relationship between organizational learning included employee empowerment and knowledge management) on one hand and organizational agility (included decision-making agility on the other hand), this paper uses extra rule performance as a mediator in the relationship between employee empowerment, knowledge management and decision-making agility, as it has not been used in this situation according to literature review, and this represents the major contribution of the present paper. Next paragraphs shows the extra-role performance

\section{Extra-role Performance}

Employee performance is considered as a critical element in the success of a firm's brand. Also, it is the reason behind its failure (Al Karim, 2019). This importance of employee performance comes from the role played by employees in attaining organizational objectives (Nabi \& Dip, 2017). Employees performance refers to the way that the human capital act to achieve the objectives and aims that designed by the top management of the organization 
(Fogaça et al., 2018). Service employees play a strategic role. They convert the philosophy of customer orientation into facts by improving service quality through service providing process (Lee et al., 2021; Moon et al., 2019). The first contact of the customers is with encounter employees; thus, the customer's impression is created based on his or her attitude after this dealing (Park, 2018). Employee performance is embodied through the interaction between the service provider (the employee) and the firm's customers. It can be considered as a mediator between employment process and achieving organizational objectives. Extrarole performance refers to the performance of the employee that goes beyond the formal tasks and duties requirements (Peñalver et al., 2019; Safavi \& Karatepe, 2018). Also, it is called organizational citizenship behaviors (OCB), it refer to actions that employees perform of their own free will (Norris, 2018). It is the actions that are non-compulsory and not recognized by any types of rewarding system of organization explicitly and that improve the effective functioning of an organization (Al Afari \& Elanain, 2014). Actually, OCB bring many benefits; it improve organizational efficiency and enhance organizational environment and relations (Gözükara \& Hatipoğlu, 2016).

Furthermore, this study deploys extra-role performance as a mediator in the relationship between employee empowerment, knowledge management and decision-making agility. According to Baron and Kenny (1986), a mediator is used to explain why or how the IVs impact the DV. A variable acts as a mediator when it meets three conditions:

1. Variations in levels of the independent variable significantly account for variations in the mediator;

2. Variations in the mediator significantly account for variations in the dependent variable;

3. When conditions 1 and 2 above are controlled, a previously significant relation between the independent and dependent variables is no longer significant.

\section{Mediating Role of Extra-role Performance between Employee Empowerment and Decision- Making Agility}

Theoretically speaking, employee empowerment and extra-role performance are linked through social exchange theory (Ahmed et al., 2012; Quratulain \& Bani-Melhem, 2020). Based on social exchange theory, organizational identifications and employee empowerment are considered as critical antecedent of both in-role and extra-role performance (Liu et al., 2011). And one of the most important strategic role of the leaders is to empower the psychological situation of their employees to keep them highly motivated towards their jobs (House, 1971; Stinson \& Johnson, 1975). Many studies concluded that employee empowerment has a significant and positive effect on employees' attitudes, perceptions and strongly associated with extra-role performance (Zeglat et al., 2014; Zhang et al., 2019). Along the same line, extra-role performance is linked with decision-making agility through resource based view theory (Dyer \& Ericksen, 2006; Saengchai \& Jermsittiparsert, 2019)

Many studies examined the impact of employee empowerment on extra-role and concluded that there is a significant positive relationship between these variables (Empowerment, 2018; Fernandez \& Moldogaziev, 2013). Employee empowerment represent critical factors that affect extra-role performance (Baird et al., 2018). Moreover, the effect of extra-role performance on decision-making agility have been examined by many scholars and concluded that extra-role performance affects organizational agility significantly (Moradi et al., 2017; Vahdati et al., 2014). Based on the previous discussion the present study hypothesizes the following: 
H3: Extra-role performance mediates the relationship between employee empowerment and decision-making agility.

\section{Mediating Role of extra-role Performance between Knowledge Management and Decision- making Agility}

Literature review revealed that knowledge management and extra-role performance are linked through knowledge based view theory (Obeidat \& Tarhini, 2016; Razzaq et al., 2019). According to the knowledge based view theory, knowledge management and its practices are strengthening employees skills and capabilities which create productive and creative employees and ultimately enhance the employee in-role and extra-role performance (Alshahrani). knowledge management plays a vital role in increasing employee efficiency in decision making and service delivery since employee with knowledge management is more positive towards his or her job duties (Mustapa \& Mahmood, 2016). Similarly, extra-role performance is linked with decision-making agility through resource based view theory of the firm (Dyer \& Ericksen, 2006; Saengchai \& Jermsittiparsert, 2019).

Many studies examined the impact of knowledge management on extra-role performance and concluded that there is a significant positive relationship between knowledge management and extra-role performance of the employee (Khanzadi \& Talei Pur, 2019; Razzaq et al., 2019). Moreover, the effect of extra-role performance on decision-making agility have been examined by many scholars and concluded that extra-role performance affects organizational agility significantly (Moradi et al., 2017; Vahdati et al., 2014). Based on the previous discussion the present study hypothesizes the following:

H4: Extra-role performance mediates the relationship between knowledge management and decision-making agility.

The previous paragraphs clarified the literature review and the hypotheses of the present study. Furthermore, the proposed theoretical framework is illustrated in Fig.1. Bellow:

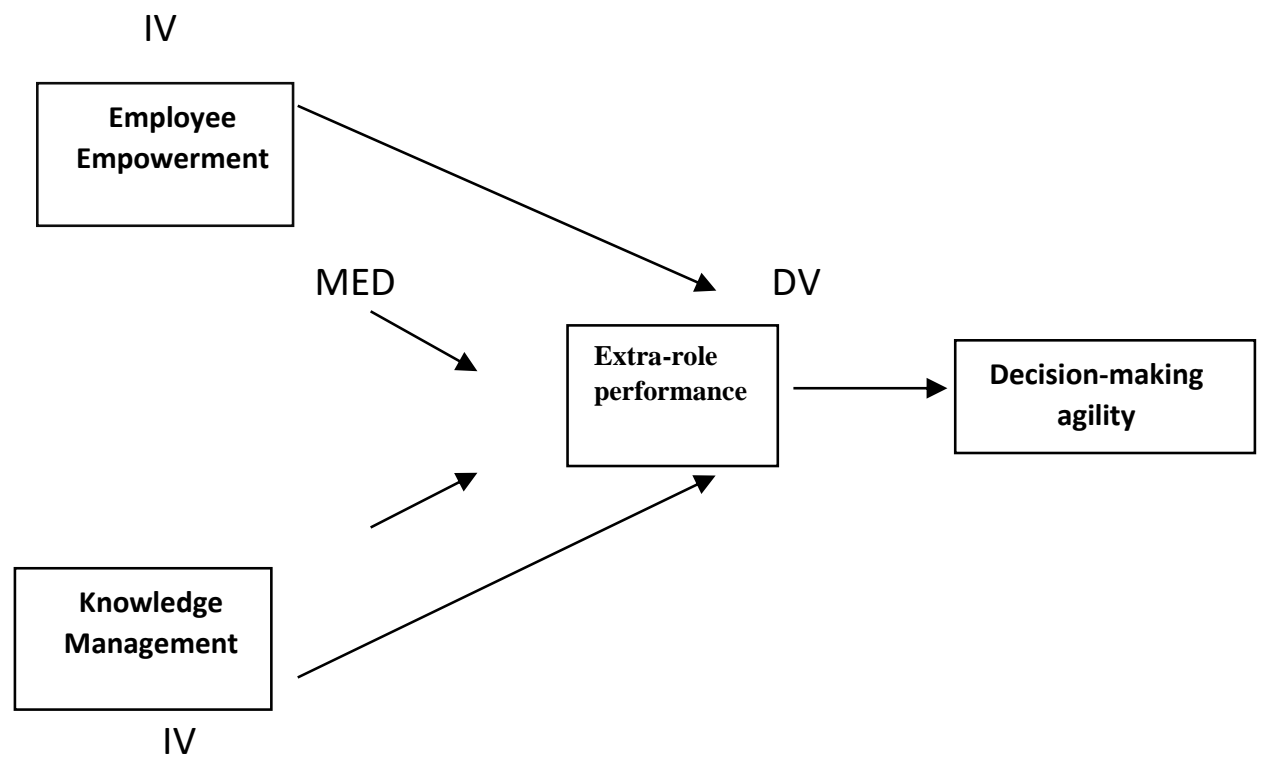

Fig.1. Research Model

\section{Research Methodology}

Survey questionnaire with a cover letter was personally distributed to the Palestinian universities employees in the West Bank. A total of 335 questionnaires were distributed in 
December 2020 and January 2021. A total of 297 questionnaires were returned. 8 of the returned questionnaire had major missing answers. Consequently, a total of 289 completed questionnaires, which represent a response rate of $86.2 \%$, were used to perform data analysis. For the purpose of testing response bias, the author performed t-test for early and late response as suggested by (Armstrong \& Overton, 1977). No statically significant differences were found in the mean score on the employee empowerment, knowledge management, extra-role performance, and decision-making agility between the early and late respondents.

\section{Variables Measurements}

This study is based on the framework that illustrated in Figure 1 above, decision-making agility (DV) was designed and measured based on previous research in the field of organizational agility (Cegarra-Navarro \& Martelo-Landroguez, 2020; Kock \& Georg Gemünden, 2016), Respondents were asked to choose their preferences from a five point Likert scale ranging from 1 (strongly disagree) to 5 (strongly agree). Employee empowerment (the first IV) was measured based on previous researches in the field of employee empowerment (Laschinger et al., 2001), Respondents were asked to choose their preferences from a five point Likert scale ranging from 1 (strongly disagree) to 5 (strongly agree) (Amitay et al., 2005). Along the same line, knowledge management was measured based on prior studies in this field (Chen \& Mohamed, 2010; Darroch, 2005). Similarly, extra-role performance (mediator) was measured by using the items adopted from Tjosvold and Yu, Respondents were asked to choose their preferences from a five point Likert scale ranging from 1 (strongly disagree) to 5 (strongly agree) (Tjosvold et al., 2004).

\section{Data Analysis and Research Results}

The collected data were analyzed by using SmartPLS 2 . Table 1 clarifies outer convergent validity statistics for all items with respect to its variables. All factor loading of the research measurements exceed the cut-off 0.70 , which reflect the consistency between construct items (Hair et al., 2010). Along the same line, reliability test of present study was confirmed as all value of composite reliability exceed the recommended cut-off 0.70 and range between 0.913 to 0.949 as illustrated in Table 1. Furthermore, the recommended standard value of average variance extracted (AVE) was found to be greater than 0.50 , in order to ensure that the latent variable has the ability to explain more than half of the variance of its indicator on average (Fornell \& Bookstein, 1982). Latent variable correlation which testing the correlations between the measures of potentially overlapping constructs is presented in Table 2 . The table shows that the values of all square root of AVE (Bold values) exceed the correlation with other constructs (elements in the rows and columns), which manifest the discriminant validity of this study. 
Table 1: Outer model, Convergent Validity and Composite Reliability

\begin{tabular}{|c|c|c|c|c|}
\hline $\begin{array}{l}\text { Constru } \\
\text { ct }\end{array}$ & Items & $\begin{array}{l}\text { Loadi } \\
\text { ng }\end{array}$ & CR & AVE \\
\hline \multirow[t]{6}{*}{ DMA } & $\begin{array}{l}\text { University collect information from different resources } \\
\text { before taking the decision }\end{array}$ & 0.803 & \multirow[t]{6}{*}{$\begin{array}{l}0.91 \\
8\end{array}$} & \multirow[t]{6}{*}{$\begin{array}{l}0.65 \\
1\end{array}$} \\
\hline & $\begin{array}{l}\text { Strategic decisions of top management lead to } \\
\text { restructuring some organizational levels in the university }\end{array}$ & 0.814 & & \\
\hline & $\begin{array}{l}\text { Our university has predetermined plans to face potential } \\
\text { financial crises }\end{array}$ & 0.812 & & \\
\hline & Our university analyses the critical sounded events quickly & 0.812 & & \\
\hline & $\begin{array}{l}\text { Our university has special data base to support decision- } \\
\text { making process }\end{array}$ & 0.776 & & \\
\hline & $\begin{array}{l}\text { University decisions process is adopting alternative } \\
\text { strategy }\end{array}$ & 0.821 & & \\
\hline \multirow[t]{5}{*}{$\mathrm{EE}$} & $\begin{array}{l}\text { Our university adopts decentralization in different } \\
\text { organizational levels }\end{array}$ & 0.830 & $\begin{array}{l}0.94 \\
9\end{array}$ & .788 \\
\hline & $\begin{array}{l}\text { the organizational levels in our university have the needed } \\
\text { independency in taking operational decisions. }\end{array}$ & 0.929 & & \\
\hline & $\begin{array}{l}\text { Our university encourages employee to share their } \\
\text { opinions and ideas }\end{array}$ & 0.924 & & \\
\hline & $\begin{array}{l}\text { University management motivate employees to find an } \\
\text { innovative methods }\end{array}$ & 0.875 & & \\
\hline & $\begin{array}{l}\text { Our university adopts employee participation in taking } \\
\text { decision process }\end{array}$ & 0.877 & & \\
\hline \multirow[t]{5}{*}{ KM } & $\begin{array}{l}\text { Top management provides the needed resources of } \\
\text { information for all employee }\end{array}$ & 0.743 & $\begin{array}{l}0.91 \\
3\end{array}$ & $\begin{array}{l}0.67 \\
9\end{array}$ \\
\hline & $\begin{array}{l}\text { We adopt scientific techniques to transfer data into useful } \\
\text { information }\end{array}$ & 0.838 & & \\
\hline & Our university provides accessibility for the employees & 0.757 & & \\
\hline & $\begin{array}{l}\text { Our employees have the efficient knowledge to perform } \\
\text { their jobs }\end{array}$ & 0.738 & & \\
\hline & $\begin{array}{l}\text { Our university uses current information as a basement of } \\
\text { future knowledge }\end{array}$ & 0.859 & & \\
\hline \multirow[t]{7}{*}{$\begin{array}{l}\text { Extra- } \\
\text { role }\end{array}$} & $\begin{array}{l}\text { I help other employees with their work when they have } \\
\text { been absent. }\end{array}$ & 0.775 & $\begin{array}{l}0.94 \\
0\end{array}$ & $\begin{array}{l}0.63 \\
9\end{array}$ \\
\hline & $\begin{array}{l}\text { I exhibit punctuality arriving at work on time in the morning } \\
\text { and after lunch breaks.. }\end{array}$ & 0.809 & & \\
\hline & $\begin{array}{l}\text { I exhibit attendance at work beyond the norm, for } \\
\text { example, take fewer days off than most individuals or } \\
\text { fewer than allowed }\end{array}$ & 0.813 & & \\
\hline & $\begin{array}{l}\text { I help others when their work load increases (assists others } \\
\text { until they get over the hurdles). }\end{array}$ & 0.802 & & \\
\hline & I give advance notice if unable to come to work. & 0.789 & & \\
\hline & $\begin{array}{l}\text { I spend a great deal of time in personal telephone } \\
\text { conversations. }\end{array}$ & 0.850 & & \\
\hline & I do not take unnecessary time off work. & 0.851 & & \\
\hline
\end{tabular}




\begin{tabular}{|l|l|l|l|l|}
\hline & I assist my supervisor to accomplish his duties & 0.761 & & \\
\cline { 2 - 4 } & $\begin{array}{l}\text { I willingly attend functions not required by the organization, } \\
\text { but helps in its overall image. }\end{array}$ & 0.736 & & \\
\hline
\end{tabular}

Table 2: Discriminant Validity- Square Root of AVE

\begin{tabular}{|c|c|c|c|c|}
\hline Constructs & $\sum_{0}^{\nwarrow}$ & 岀 & 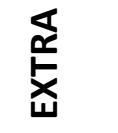 & $\sum_{\underline{x}}$ \\
\hline DMA & 0.807 & & & \\
\hline $\mathrm{EE}$ & 0.442 & 0.888 & & \\
\hline EXTRA & 0.853 & 0.454 & 0.799 & \\
\hline KM & 0.548 & 0.575 & 0.696 & 0.824 \\
\hline
\end{tabular}

After assuring measurements of validity and reliability of the present study, the author proceeded the bootstrapping approach to test research hypotheses. Path coefficients of the research hypotheses are illustrated in Table 3. The first set of research hypotheses $(\mathrm{H} 1-\mathrm{H} 2)$ hypothesized that, employee empowerment and knowledge management are positively associated with decision-making agility. The coefficient on the path from employee empowerment and knowledge management to decision-making agility $(\mathrm{H} 1, \mathrm{H} 2)$ was rejected as the $p$-value is greater than 0.01. in particularly, $(P=0.014),(P=0.015)$ respectively. This concludes that employee empowerment and knowledge management have no direct effect on decision-making agility at Palestinian universities.

Table 3: Path Coefficient of the Research Hypotheses

\begin{tabular}{lllll}
\hline Relationships & Std. Beta & Std. Error & P-value & Decision \\
\hline EE -> DMA & 0.116 & 2.196 & 0.014 & Rejected \\
KM -> DMA & 0.146 & 2.182 & 0.015 & Rejected \\
\hline \multicolumn{5}{c}{ Significant at $P^{*}<0.01$}
\end{tabular}

Similarly, bootstrapping was run to test the mediating role of extra-role performance between employee empowerment and knowledge management and decision-making agility $(\mathrm{H} 3, \mathrm{H} 4)$. The results are illustrated in Table 4 and Table 5.

Table 4: Mediating role of extra-role performance between employee empowerment and decision-making agility

\begin{tabular}{lllll}
\hline Relationship & Std. Beta & $\begin{array}{l}\text { Std. } \\
\text { Error }\end{array}$ & $\begin{array}{l}\text { P- } \\
\text { value }\end{array}$ & $\begin{array}{l}\text { Decisio } \\
\mathbf{n}\end{array}$ \\
\hline EE $\rightarrow$ Extra (Path & 0.43 & 0.025 & 0.000 & Accept \\
Extra $\rightarrow$ DMA & 0.53 & 0.057 & 0.000 & Accept \\
EE $\rightarrow$ DMA (Path & 0.77 & 0.037 & 0.000 & Accept \\
\hline \multicolumn{6}{c}{ Significant at $\mathrm{P}^{*}<0.01$} &
\end{tabular}

Actually, the three conditions of mediating have been met. Thus, it can be concluded that extra-role performance mediates the relationship between employee empowerment and knowledge management on one hand and decision-making agility on the other hand satisfaction at $t$ value $>1.96$. Based on that, $\mathrm{H} 3$ and $\mathrm{H} 4$ have been accepted. 
Table 5: Mediating role of extra-role performance between knowledge management and decision-making agility

\begin{tabular}{lllll}
\hline Relationships & $\begin{array}{l}\text { Std. } \\
\text { Beta }\end{array}$ & $\begin{array}{l}\text { Std. } \\
\text { Erro } \\
\text { r }\end{array}$ & $\begin{array}{l}\text { P- } \\
\text { valu } \\
\text { e }\end{array}$ & Decision \\
\hline KM $\rightarrow$ Extra (Path a) & 0.83 & 0.02 & 0.00 & Accept \\
Extra $\rightarrow$ DMA (Path $b)$ & 0.47 & 0.05 & 0.00 & Accept \\
KM $\rightarrow$ DMA (Path $\left.c^{\prime}\right)$ & 0.47 & 0.05 & 0.00 & Accept \\
\hline \multicolumn{4}{c}{ Significant at $\mathrm{P}^{*}<0.01$} \\
\end{tabular}

\section{Discussion and Conclusion}

This paper sought to test the effect of employee empowerment and knowledge management on decision-making agility of Palestinian universities, and then to examine the mediating role of extra-role performance between (employee empowerment and knowledge management) and decision-making agility. The first hypothesis of this study hypothesized that there is a significant positive relationship employee empowerment and decision-making agility. The coefficient on this path was rejected at $(P=0.014)$. This concludes there is no direct relationship between employee empowerment and decision-making agility. Moreover, The second hypothesis of the present study hypothesized that there is a significant positive relationship between knowledge management and decision-making agility. The coefficient on this path was rejected at $(P=0.015)$. This concludes there is no direct relationship between knowledge management and decision-making agility.

Along the same line, literature review revealed that few researches tested the direct relationships between employee empowerment and organizational agility (Nouri \& Mir Mousavi, 2020; Elgamal, 2018; Muduli, 2017) and found this relationships positive and significant. For instance, Asgarnezhad and Mousavi (2020) examined the impact of employee empowerment on organizational agility in Iranian context and concluded that the result is positive and significant. Also, Muduli (2017) examined the effect of employee empowerment on organizational agility in India, and the result was positive. On the other hand, large number of previous studies concluded that the relationship between employee empowerment and organizational agility is indirect relationship, and tested it through other variables (Mediators). Similarly, knowledge management and organizational agility link was examined by many scholars (Ashrafi et al., 2006; Liu et al., 2014; Mehdibeigi et al., 2016) and concluded that knowledge management has impact on organizational agility. For instance, Liu et al,. (2014) examined the relationship between knowledge management and organizational agility in Chinese context and found that knowledge management has direct relationship with organizational agility. Similarly, other scholars concluded that the relationship between knowledge management and organizational agility is indirect (Bahrami et al., 2016; Hassan et al., 2013).

Based on the above discussion, this study considers its results as a logical finding; in other words, decision-making agility describes the organizational activities that aim to interpret the observed events, define threats and opportunities, and make the decisions based on this basis in order to maximize the profits and minimize the risks (Zareravasan \& Ashrafi, 2019). And employee empowerment enables employees to feel that they are essential part of organizational success. it builds high commitment among employees and leads to greater use of the abilities and skills of the human pool, thus It enhances team working and if there is meaningful participation which lead to effective and efficient role of determining the critical 
events surrounded the organization since these employees are working in all departments and doing their jobs in all aspects of the organization. Similarly knowledge management supports the internal system of the organization to be agile in terms of decision-making agility, since knowledge management maximizes the exchange of information among stakeholders, promoting the generation of innovations and contributes critically in cooperation within the organization's departments, and the flow of information in the organizations creates changes in knowledge that is beneficial to organizations, in other words, knowledge management help organizations to share information from economic sectors and different groups of employees and then gain an important strategic positions.

Determine whether extra-role performance plays a mediating role (employee empowerment and knowledge management) and decision-making agility in Palestinian universities. For that, Hypotheses 3 states that "extra-role performance mediates the relationship between employee empowerment and decision-making agility and Hypothesis 4 states that "extra-role performance mediates the relationship between knowledge management and decisionmaking agility, were examined using PLS-SEM path modeling analysis. The findings show that relationship between (employee empowerment and knowledge management) and decisionmaking agility is mediated by extra-role performance.

According to the results of this study, employee empowerment and knowledge management Palestinian universities develop and generate the decision-making agility. No previous researches tested the mediating role of extra-role performance between these two variables and decision-making agility according to literature review and this is the major contribution of the present study. Based on that, the leaders of Palestinian universities must enhance employee empowerment and knowledge management, since these variables represent a very vital way toward developing the decision-making agility as well as the overall performance of the universities.

\section{Recommendations for Future Researchers}

The above mentioned review discussions lead to the following list of suggested studies for improving the organizational agility:

$>$ Employee empowerment, knowledge management and respond agility; mediating role of extra-role performance.

$>$ Does in-role performance mediates the relationship between firm strategy and decision-making agility.

$>$ Internal communication, knowledge management and decision agility; mediation role of in-role performance.

\section{References}

Abtahi, S., \& Abbasi, S. (2007). Empowering employers, Karaj. Institute of management researches and educations.(In Persian).

Ahmed, I., Ismail, W. K. W., Amin, S. M., Ramzan, M., \& Khan, M. (2012). A look at social exchange at work: A literature survey approach. World Applied Sciences Journal, 19(7), 951-956.

Akhtar, C. S., \& Arif, A. (2011). Impact of organizational learning on organizational performance: Study. Int. J. Acad. Res, 3(5), 327-331.

Al-Romeedy, B. S. (2019). Strategic Agility as a Competitive Advantage in Airlines-Case Study: Egypt Air. Journal of the Faculty of Tourism and Hotels-University of Sadat City, 3(1), 1-15. 
Al Afari, T. S., \& Elanain, H. M. A. (2014). Procedural and distributive justice as mediators of the relationship between interactional justice and work outcomes: An empirical study of the UAE public health care sector. Journal of Applied Business Research (JABR), 30(4), 1091-1108.

Al Karim, R. (2019). Impact of different training and development programs on employee performance in Bangladesh perspective. International Journal of Entrepreneurial Research, 2(1), 8-14.

Alalie, H. M., Harada, Y., \& Noor, I. M. (2019). The Impact of Employee Empowerment in a Sustainable Competitive Advantage of Iraqi Private Banks. International Journal of Liberal Arts and Social Science, 7(2), 1-11.

Alonso-Almeida, M. D. M., Celemín-Pedroche, M. D. I. S., Rodríguez-Antón, M. J., \& RubioAndrada, L. (2016). Human and other critical factors in organizational learning in the hotel industry: A contingency approach. Tourism \& Management Studies, 12(1), 97106.

Alromaihi, M. A., Alshomaly, Z. A., \& George, S. (2017). Job satisfaction and employee performance: A theoretical review of the relationship between the two variables. International Journal of Advanced Research in Management and Social Sciences, 6(1), 1-20.

Alshaibani, E., \& Bakir, A. (2017). A reading in cross-cultural service encounter: Exploring the relationship between cultural intelligence, employee performance and service quality. Tourism and Hospitality Research, 17(3), 249-263.

Amitay, M., Popper, M., \& Lipshitz, R. (2005). Leadership styles and organizational learning in community clinics. Learning Organization, The, 12(1), 57-70.

Nouri, A. B., \& Mousavi, M. (2020). Effect of cooperative management on organizational agility with the mediating role of employee empowerment in public transportation sector. Cuadernos de Gestión, 20(2), 15-46.

Ashori, H., Veisari, E. F., \& Taghavi, S. A. (2015). The Relationship between the Organization Agility and Mental Health of Staff on Strategic Preparation for Crisis Management: The case study in Islamic Azad Universities of Mazandaran. International Journal of Management Sciences, 6(5), 272-281.

Ashrafi, N., Xu, P., Kuilboer, J., \& Koehler, W. (2006). Boosting enterprise agility via IT knowledge management capabilities. Proceedings of the 39th Annual Hawaii International Conference on System Sciences (HICSS'06),

Bahrami, M. A., Kiani, M. M., Fallahzadeh, H., Montazeralfaraj, R., \& Mohammadzadeh, M. (2016). Relationship between organizational learning and organizational agility in teaching hospitals of Yazd. Management Strategies in Health System, 1(1), 71-80.

Bahrami, M. A., Kiani, M. M., Montazeralfaraj, R., Zadeh, H. F., \& Zadeh, M. M. (2016). The mediating role of organizational learning in the relationship of organizational intelligence and organizational agility. Osong public health and research perspectives, 7(3), 190-196.

Baird, K., Su, S., \& Munir, R. (2018). The relationship between the enabling use of controls, employee empowerment, and performance. Personnel Review.

Cegarra-Navarro, J.-G., \& Martelo-Landroguez, S. (2020). The effect of organizational memory on organizational agility. Journal of Intellectual Capital. https://doi.org/10.1108/JICO32019-0048.

Center, P. I. (2018). Higher Education in Palestine, Reality and Challanges https://www.palinfo.com/news/, 26/5/2021 
Chen, L., \& Mohamed, S. (2010). The strategic importance of tacit knowledge management activities in construction. Construction Innovation, 10(2), 138-163.

Darroch, J. (2005). Knowledge management, innovation and firm performance. Journal of knowledge management, 9(3), 101-115.

Demir, A., Budur, T., Omer, H. M., \& Heshmati, A. (2021). Links between knowledge management and organisational sustainability: does the ISO 9001 certification have an effect? Knowledge Management Research \& Practice, DOI:10.1080/14778238.2020.1860663.

Dyer, L., \& Ericksen, J. (2006). Dynamic organizations: Achieving marketplace agility through workforce scalability. Cornell University. School of Industry and Labor Relations. Center of Advanced Human Resource Studies. Ithaca, NY.

Elgamal, M. (2018). Dynamic organizational capabilities: the joint effect of agility, resilience and empowerment. Journal of Human Resource Management, 6(2), 44-49.

Emam, A. S., Jais, J. B., \& Tabash, M. I. (2019). The role of tribalism as mediator between employee empowerment and organizational commitment in Yemeni Islamic banking sector. Management \& Marketing, 14(1), 130-149.

Empowerment, W. E. (2018). A review of literature on the associations among employee empowerment, work engagement and employee performance. Modern Applied Science, 12(11), 313-329.

Ferrier, W. J., \& Lyon, D. W. (2004). Competitive repertoire simplicity and firm performance: The moderating role of top management team heterogeneity. Managerial and decision economics, 25(6-7), 317-327.

Fogaça, N., Rego, M. C. B., Melo, M. C. C., Armond, L. P., \& Coelho Jr, F. A. (2018). Job performance analysis: scientific studies in the main journals of management and psychology from 2006 to 2015. Performance Improvement Quarterly, 30(4), 231-247.

Fornell, C., \& Bookstein, F. L. (1982). Two structural equation models: LISREL and PLS applied to consumer exit-voice theory. Journal of Marketing research, 19(4), 440-452.

Govareshki, M., Hosseini, S., \& Taghinejad, R. (2017). Use of knowledge maps in collaborative networks management (case study: SSFR company). International Journal of Computer Science and Network Security, 17(9), 21-28.

Gözükara, I., \& Hatipoğlu, Z. (2016). The effect of employer branding on employees' organizational citizenship behaviors. International Journal of Business Management \& Economic Research, 7(1), 37-57.

Hair, J. F., Black, W. C., Babin, B. J., \& Anderson, R. E. (2010). Multivariate data analysis: A global perspective (7th ed.). Pearson Prentice Hall, USA.

Hasan, M. R. (2020). Employee Empowering and Its Positive Effect: A Critical Review. BUFT J. of Business \& Economics (BJBE), 1, 229-242.

Hassan, N. H. B., Arshad, N. I. B., Mustapha, E. E. B., \& Jaafar, J. B. (2013). A literature review: Exploring organizational learning orientation as antecedent of Information Technology (IT) infrastructure capability to achieve organizational agility. 2013 International Conference on Research and Innovation in Information Systems (ICRIIS), 2013, pp. 204-209, doi: 10.1109/ICRIIS.2013.6716709.,

Hong, J. (1999). Structuring for organizational learning. The learning organization, 6(4), 173186.

Farahani, H. A., \& Salimi, F. (2015). The Study of the Relationship between Employees' Empowerment and Organizational Agility: A Case Study in Azarab Industrial Company. European Online Journal of Natural and Social Sciences: Proceedings, 4(1 ), 1067-1075. 
Hosein, Z. Z., \& Yousefi, A. (2012). The role of emotional intelligence on workforce agility in the workplace. International Journal of Psychological Studies, 4(3), 48-57.

House, R. J. (1971). A path goal theory of leader effectiveness. Administrative science quarterly, 16(3), 321-339.

Ihuoma, P. C., Epelle, S. E., KALU, L. A., \& Sotonye, P. M. (2019). Staff Empowerment as a Tool for Increasing Orgarnizational Performance: A Study of Non-Academic Junior Staff in Federal Polytechnic of Oil and Gas Bonny. International Journal of Engineering and Management Research, 9(4), 40-46.

Jia, L., Shaw, J. D., Tsui, A. S., \& Park, T.-Y. (2014). A social-structural perspective on employee-organization relationships and team creativity. Academy of Management Journal, 57(3), 869-891.

Jiang, X., \& Li, Y. (2008). The relationship between organizational learning and firms' financial performance in strategic alliances: A contingency approach. Journal of world business, 43(3), 365-379.

Khan, H., \& Wisner, J. D. (2019). Supply chain integration, learning, and agility: Effects on performance. Journal of Operations and Supply Chain Management, 12(1), 14.

Khanzadi, H., \& Pur, T. M. (2019). Investigating the Effect of Knowledge Management Strengthening Factors in Optimizing the Performance of IRI Navy Organization. Journal of Research on Management of Teaching in Marine Sciences, 6(1), 48-56.

Kock, A., \& Gemünden, G. H. (2016). Antecedents to decision-making quality and agility in innovation portfolio management. Journal of Product Innovation Management, 33(6), 670-686.

Laschinger, H. K. S., Finegan, J., Shamian, J., \& Wilk, P. (2001). Impact of structural and psychological empowerment on job strain in nursing work settings: expanding Kanter's model. JONA: The Journal of Nursing Administration, 31(5), 260-272.

Lee, C. M. J., Che-Ha, N., \& Alwi, S. F. S. (2021). Service customer orientation and social sustainability: The case of small medium enterprises. Journal of Business Research, 122, 751-760.

Liu, H., Song, D., \& Cai, Z. (2014). Knowledge Management Capability and Firm Performance: the Mediating Role of Organizational Agility. PACIS.

https://citeseerx.ist.psu.edu/viewdoc/download?doi=10.1.1.1062.8413\&rep=rep1\&ty $p e=p d f$.

Liu, Y., Loi, R., \& Lam, L. W. (2011). Linking organizational identification and employee performance in teams: The moderating role of team-member exchange. The International Journal of Human Resource Management, 22(15), 3187-3201.

Manab, N., \& Aziz, N. (2019). Integrating knowledge management in sustainability risk management practices for company survival. Management Science Letters, 9(4), 585594.

Martins, V. W. B., Rampasso, I. S., Anholon, R., Quelhas, O. L. G., \& Filho, L. W. (2019). Knowledge management in the context of sustainability: Literature review and opportunities for future research. Journal of Cleaner Production, 229, 489-500.

Masa'deh, R. E., Obeidat, B. Y., \& Tarhini, A. (2016). A Jordanian empirical study of the associations among transformational leadership, transactional leadership, knowledge sharing, job performance, and firm performance. Journal of Management Development, 35(5), 681-705. 
Mehdibeigi, N., Dehghani, M., \& Yaghoubi, M. N. (2016). Customer knowledge management and organization's effectiveness: Explaining the mediator role of organizational agility. Procedia-Social and Behavioral Sciences, 230, 94-103.

Mohapatra, I., \& Sundaray, B. K. (2018). Impact of employee empowerment on employee performance. International Journal of Advanced Technology and Engineering Research, National Conference on Recent Trends in Science, Technology and Management. (IJATER), 1, 98-102.,

Moon, T. W., Hur, W.-M., \& Hyun, S. S. (2019). How service employees' work motivations lead to job performance: The role of service employees' job creativity and customer orientation. Current Psychology, 38(2), 517-532.

Moradi, A. S., Haddadi, E., \& Keikha, A. (2017). Investigating the Effect of Organizational Citizenship (OCB) Behavior Components on Organizational Agility. Interdisciplinary Journal of Education, 2(1), 59-67.

Muduli, A. (2017). Workforce agility: Examining the role of organizational practices and psychological empowerment. Global Business and Organizational Excellence, 36(5), 46-56.

Murray, W. C., \& Holmes, M. R. (2021). Impacts of Employee Empowerment and Organizational Commitment on Workforce Sustainability. Sustainability, 13(6), 3163.

Mustapa, A. N., \& Mahmood, R. (2016). Knowledge management and job performance in the public sector: The moderating role of organizational commitment. International Journal of Research in Business Studies and Management, 3(7), 28-36.

Putri, N. D., \& Mangundjaya, W. (2020). Examining the Effects of Organizational Learning on Workforce Agility through Psychological Empowerment. Open Journal for Psychological Research, 4(2), 86-94.

Nasiri, R., Mollahosseini, A., Salajegheh, S., \& Sheikhy, A. (2018). Impact of Empowering Communication Technology Practices on Service Performance in Information Technology Sector. International Journal of Information and Communication Technology Research, 10(2), 45-55.

Nazir, O., \& Islam, J. U. (2017). Enhancing organizational commitment and employee performance through employee engagement. South Asian Journal of Business Studies, 6(1), 98-114.

Nguyen, H., Groth, M., Walsh, G., \& Hennig-Thurau, T. (2014). The impact of service scripts on customer citizenship behavior and the moderating role of employee customer orientation. Psychology \& Marketing, 31(12), 1096-1109.

Nguyen, N., \& Leclerc, A. (2011). The effect of service employees' competence on financial institutions' image: benevolence as a moderator variable. Journal of services marketing, 25(5), 349-360.

Nisar, T. M., Prabhakar, G., \& Strakova, L. (2019). Social media information benefits, knowledge management and smart organizations. Journal of Business Research, 94, 264-272.

Norris, S. E. (2018). The Business Education of Charismatic Leaders and Good Soldiers. International Journal of Adult Vocational Education and Technology (IJAVET), 9(2), 1129.

Novitasari, D., Asbari, M., \& Purwanto, A. (2020). Maximizing Employee Performance: An Analysis of Organizational and Individual Factors. International Journal of Social and Management Studies, 1(1), 95-104. 
Nabi, N. I. M., \& Dip TM, H. A. (2017). Impact of motivation on employee performances: a case study of Karmasangsthan bank Limited, Bangladesh. Arabian J Bus Manag Review, 7(293), 2-8.

Omotayo, F. O. (2015). Knowledge Management as an important tool in Organisational Management: A Review of Literature. Library Philosophy and Practice, 1(2015), 1-23.

Pantouvakis, A., \& Bouranta, N. (2017). Agility, organisational learning culture and relationship quality in the port sector. Total Quality Management \& Business Excellence, 28(3-4), 366-378.

Park, J.-J. (2018). A Study on Organizational Citizenship Behaviors and Service Quality as External Effectiveness of Contact Employees for Deluxe Hotel in Seoul. Journal of Convergence for Information Technology, 8(1), 215-225.

Peñalver, J., Salanova, M., Martínez, I. M., \& Schaufeli, W. B. (2019). Happy-productive groups: How positive affect links to performance through social resources. The Journal of Positive Psychology, 14(3), 377-392.

Pun, K. F., \& Nathai-Balkissoon, M. (2011). Integrating knowledge management into organisational learning. The learning organization, 18(3), 203-223.

Purnomo, S., Rahayu, E. S., RIANI, A. L., Suminah, S., \& Udin, U. (2020). Empowerment model for sustainable tourism village in an emerging country. The Journal of Asian Finance, Economics, and Business, 7(2), 261-270.

Quratulain, S., \& Bani-Melhem, S. (2020). Perceived organizational customer orientation and frontline employees' innovative behaviors: exploring the role of empowerment and supervisory fairness. European Journal of Innovation Management, 24(2), 533-552.

Rashwan, A. (2020). Challenges and Obstacles of Using Computerized e-learning in Palestinian Universities during COVID 19 Pandemic Journal of Economic Researcher $8(2), 75-89$.

Rastegari, H., Hosseini, S. H., \& Ghayoor, H. (2020). Designing and developing the strategic foresight capabilities of medical universities in the accidents and crises of the country with emphasis on human resource agility. International Journal of Logistics Systems and Management, 36(1), 124-137.

Ravichandran, T. (2018). Exploring the relationships between IT competence, innovation capacity and organizational agility. The Journal of Strategic Information Systems, 27(1), 22-42.

Razzaq, S., Shujahat, M., Hussain, S., Nawaz, F., Wang, M., Ali, M., \& Tehseen, S. (2019). Knowledge management, organizational commitment and knowledge-worker performance. Business process management journal, 25(5), 923-947.

Read III, J. B. (2020). A decade of teaching followership: retrospective and guide. Industrial and Commercial Training, 53(2), 166-174.

Rulinawaty, S. A., \& Samboteng, L. (2020). Leading Agile Organization Can Indonesian Bureaucracy Become Agile? Journal of Talent Development and Excellence, 12(3s), 330-338.

Saengchai, S., \& Jermsittiparsert, K. (2019). Coping Strategy to Counter the Challenges towards Implementation of Industry 4.0 in Thailand: Role of Supply Chain Agility and Resilience. Int. J Sup. Chain. Mgt vol, 8(5), 733.

Safavi, H. P., \& Karatepe, O. M. (2018). High-performance work practices and hotel employee outcomes. International Journal of Contemporary Hospitality Management, 30(2), 1112-1133. 
Santoro, G., Vrontis, D., Thrassou, A., \& Dezi, L. (2018). The Internet of Things: Building a knowledge management system for open innovation and knowledge management capacity. Technological forecasting and social change, 136, 347-354.

Shukla, A., Singh, S., Rai, H., \& Bhattacharya, A. (2018). Employee empowerment leading to flexible role orientation: A disposition-based contingency framework. IIMB management review, 30(4), 330-342.

Singh, S. K., \& El-Kassar, A.-N. (2019). Role of big data analytics in developing sustainable capabilities. Journal of Cleaner Production, 213, 1264-1273.

Sohrabi, R., Asari, M., \& Hozoori, M. J. (2014). Relationship between workforce agility and organizational intelligence (case study: The Companies of" Iran High Council of Informatics"). Asian Social Science, 10(4), 279-287.

Sukati, I., Hamid, A. B., Baharun, R., Yusoff, R. M., \& Anuar, M. A. (2012). The effect of organizational practices on supply chain agility: An empirical investigation on Malaysia manufacturing industry. Procedia-Social and Behavioral Sciences, 40, 274-281.

Tallon, P. P., \& Pinsonneault, A. (2011). Competing perspectives on the link between strategic information technology alignment and organizational agility: insights from a mediation model. MIS quarterly, 463-486.

Tjosvold, D., Yu, Z. Y., \& Hui, C. (2004). Team learning from mistakes: the contribution of cooperative goals and problem-solving. Journal of management studies, 41(7), 12231245.

Tooranloo, H. S., \& Saghafi, S. (2018). The relationship between organisational agility and applying knowledge management. International Journal of Agile Systems and Management, 11(1), 41-66.

Vahdati, H., Nejad, S. H. M., \& Abulfazl, S. (2014). The Achievement of organizational Agility through the Organizational Citizenship Behavior and the Intellectual Capital. Indian Journal of Scientific Research, 4(3), 51-58.

Winby, S., \& Worley, C. G. (2014). Management processes for agility, speed, and innovation. Organizational Dynamics, 43(3), 225-234.

Yousif, M., \& Pessi, K. (2016). It Agility Research Review: Thematic Analysis and Categorization of literature. Paper presented at the publishing at: 20th Pacific Asia Conference on Information Systems, June 27-July 1, 2016, Chiayi, Taiwan.,

Zareravasan, A., \& Ashrafi, A. (2019). An empirical investigation on big data analytics (BDA) and innovation performance. In Proceedings of the 3rd International Conference on Business and Information. Management-ICBIM '19, Paris, France, 12-14 September 2019; pp. 97-101,

Zeglat, D., Aljaber, M., \& Alrawabdeh, W. (2014). Understating the impact of employee empowerment on customer-oriented behavior. Journal of Business Studies Quarterly, 6(1), 55-67.

Zhang, R. Y., Liu, X. M., Wang, H. Z., \& Shen, L. (2011). Service climate and employee service performance: exploring the moderating role of job stress and organizational identification. The Service Industries Journal, 31(14), 2355-2372.

Zhang, Y., Luo, Y., Zhang, X., \& Zhao, J. (2019). How green human resource management can promote green employee behavior in China: A technology acceptance model perspective. Sustainability, 11(19), 1-19. 